\title{
Brownfield site rehabilitation: a Canadian perspective
}

\author{
K. H. Tiedemann \\ Applied Economics Consulting and Simon Fraser University, Canada
}

\begin{abstract}
Years of neglect have left a legacy of contaminated and underutilized brownfield sites in Canada, with attendant environmental, social and economic costs. Rehabilitation of brownfield sites has emerged as a major public issue in Canada over the past twenty years. This paper explores several dimensions of the brownfields issue in Canada: the size and nature of the brownfields situation by province; the role and extent of federal and provincial government regulatory activities and financing programs; and the cost effectiveness of brownfields site rehabilitation efforts.
\end{abstract}

Keywords: brownfield sites, environmental policy, cost effectiveness.

\section{Introduction}

Rehabilitation of brownfield sites has emerged as major public issue in Canada over the past twenty years. Years of neglect have left a legacy of contaminated and underutilized commercial and industrial brownfield sites. As indicated in the references, a number of studies have explored various aspects of the brownfields situation in Canada, but there have been few attempts to examine the environmental, policy and economic aspects of brownfields in Canada. This study attempts to help fill this gap by exploring the following related issues: (1) estimate the number of brownfield sites by province and characterize these sites; (2) review federal and provincial brownfields policies; and (3) undertake a cost effectiveness analysis of brownfield sites rehabilitation.

\section{Canadian brownfields situation}

The extent and nature of the brownfield sites situation varies considerably by province across Canada as shown in Table 1, but there are common features 
within each region. Table 1 provides the number of sites in each province, describes the locations and types of sites, and summarizes the causes for brownfield sites in the province.

British Columbia is estimated to have about 200 brownfield sites. The sites are concentrated in the major population centres of Vancouver, the remainder of the Lower Mainland and Victoria. The sites are related to historical poor environmental practices in the primary production industries of coal mining, metal mining, wood processing and pulp and paper production, which have been the historical basis of the economy.

The prairie provinces of Alberta, Saskatchewan and Manitoba together have about 95 brownfield sites. The sites are concentrated in Edmonton, Calgary, Regina, Saskatoon and Winnipeg, but Alberta has a number of significantly contaminated sites due to oil and natural gas production and processing in rural areas. The economies of the prairie provinces have undergone major transformations over the past fifty years, leading to relocation of economic activity away from downtown areas with their railway infrastructure and associated resource processing activities.

Ontario has about 1,500 brownfield sites. They are concentrated in the current and former manufacturing centres of Toronto, Hamilton, Kingston and Cornwall. Industrial development in Ontario occurred earlier than in Western Canada, at a time when little attention was paid to environmental issues. As large multi-story factories became uneconomic to operate, substantial urban areas were gradually abandoned, leaving become a trail of spills, piles of waste and illegal and casual dumping of toxic materials.

Quebec has perhaps 1,000 brownfield sites, second to only Ontario, but it probably has the largest area of brownfield sites. Many sites are along the St. Lawrence River in Quebec City, Trois Riveres, Shawinigan and Montreal. Quebec has suffered a significant decline in its industrial base since 1980, and this has led to a significant expansion in the number and total area of brownfield sites in the province. As is the case for Ontario, industrialization occurred early in Quebec at a time when environmental concerns were not on the public agenda.

The maritime provinces of New Brunswick, Prince Edward Island, Nova Scotia and Newfoundland have a total of perhaps 120 brownfield sites. There are major abandoned industrial operations in Halifax, St. John, St. John's and Fredericton. The Sydney Tar Ponds and Coke ovens may be the single most important toxic site in Canada, in terms of its long term impacts on the health of the surrounding population and the costs of clean up and rehabilitation. In May 2004, the Governments of Canada and Nova Scotia announced a joint ten-year, $\$ 400$ million program for the ponds.

\section{Federal and provincial policies and programs}

The management and development of brownfield sites in Canada is affected by policies and programs at the federal, provincial and municipal levels. Table 2 provides information on federal and provincial policies including policies on contaminated sites, fuel tanks, waste generation and financing. 
Table 1: $\quad$ Brownfield sites situation by province.

\begin{tabular}{|c|c|c|c|}
\hline Province & $\begin{array}{l}\text { No. of } \\
\text { sites }\end{array}$ & Locations and types & Causes \\
\hline $\begin{array}{l}\text { British } \\
\text { Columbia }\end{array}$ & 200 & $\begin{array}{l}\text { Manufacturing and commercial } \\
\text { in larger centres, smelters, wood } \\
\text { processing, coal gasification, } \\
\text { foundries, galvanizing operations } \\
\text { in rural areas }\end{array}$ & $\begin{array}{l}\text { Historical practices of site } \\
\text { operators left soil and } \\
\text { ground water contaminated, } \\
\text { and re- development often } \\
\text { requires costly remediation, } \\
\text { potential legal liability of } \\
\text { new owners }\end{array}$ \\
\hline Alberta & 50 & $\begin{array}{l}\text { Across the province, closed } \\
\text { service stations, wood preserving } \\
\text { facilities, oil and gas facilities }\end{array}$ & $\begin{array}{l}\text { Financial costs of } \\
\text { rehabilitation major cause of } \\
\text { brownfield sites and } \\
\text { population movement to } \\
\text { urban areas }\end{array}$ \\
\hline Saskatchewan & 20 & $\begin{array}{l}\text { Exclusively urban, abandoned } \\
\text { refineries, herbicide plants, scrap } \\
\text { metal operations, landfills, } \\
\text { National Defense sites }\end{array}$ & $\begin{array}{l}\text { Population movement trends } \\
\text { urban areas with consequent } \\
\text { abandonment of sites, } \\
\text { railway facilities closures }\end{array}$ \\
\hline Manitoba & 25 & $\begin{array}{l}\text { Generally urban, abandoned fuel } \\
\text { service sites and industrial sites, } \\
\text { rural service stations }\end{array}$ & $\begin{array}{l}\text { Historical closure of } \\
\text { facilities and environmental } \\
\text { accidents with high potential } \\
\text { site clean up costs }\end{array}$ \\
\hline Ontario & 1,500 & $\begin{array}{l}\text { Urban areas especially in } \\
\text { Southern Ontario, coal gas } \\
\text { plants, associated industries such } \\
\text { as roofing materials, unique } \\
\text { examples of steel mills, refining } \\
\text { and petrochemical, metal } \\
\text { refining }\end{array}$ & $\begin{array}{l}\text { Early industrialization of } \\
\text { province occurred at time } \\
\text { when environmental } \\
\text { sensitivity lacking, urban } \\
\text { sprawl led to abandoned } \\
\text { industrial and transportation } \\
\text { sites, substantial } \\
\text { rehabilitation costs to meet } \\
\text { environmental legislation }\end{array}$ \\
\hline Quebec & 1,000 & $\begin{array}{l}\text { Major urban areas especially } \\
\text { along the St. Lawrence River, } \\
\text { including mainly abandoned } \\
\text { transportation, distribution and } \\
\text { industrial sites, including oil } \\
\text { refineries, chemical plants and } \\
\text { metal works }\end{array}$ & $\begin{array}{l}\text { Historical factors similar to } \\
\text { Ontario, decline of industrial } \\
\text { activities since } 1980 \\
\text { combined with population } \\
\text { shifts from urban areas to } \\
\text { suburban areas made } \\
\text { redevelopment less attractive }\end{array}$ \\
\hline $\begin{array}{l}\text { New } \\
\text { Brunswick }\end{array}$ & 40 & $\begin{array}{l}\text { Urban areas including industry } \\
\text { and service stations }\end{array}$ & $\begin{array}{l}\text { Mainly site rehabilitation } \\
\text { costs }\end{array}$ \\
\hline $\begin{array}{l}\text { Prince } \\
\text { Edward Is. }\end{array}$ & 0 & No significant sites & No major issues \\
\hline Nova Scotia & 40 & $\begin{array}{l}\text { Urban areas including rail } \\
\text { transportation, industry and } \\
\text { service stations, also rural } \\
\text { mining sites, Department of } \\
\text { Defense sites }\end{array}$ & $\begin{array}{l}\text { Mainly site rehabilitation } \\
\text { costs }\end{array}$ \\
\hline $\begin{array}{l}\text { Newfound- } \\
\text { land }\end{array}$ & 40 & $\begin{array}{l}\text { Urban areas including industry } \\
\text { and service stations }\end{array}$ & $\begin{array}{l}\text { Decline of fisheries } \\
\text { industrial base, but mainly } \\
\text { site rehabilitation costs }\end{array}$ \\
\hline Total & 2,915 & & \\
\hline
\end{tabular}

Sources: NRTEE, Provincial Government Websites. 
Table 2: Provincial and federal programs.

\begin{tabular}{|c|c|c|c|c|}
\hline & $\begin{array}{l}\text { Contaminated } \\
\text { sites }\end{array}$ & Fuel tanks & $\begin{array}{l}\text { Waste } \\
\text { generation }\end{array}$ & Financing \\
\hline British Columbia & $\begin{array}{l}\text { Voluntary } \\
\text { reporting, risk- } \\
\text { based clean up } \\
\text { guidelines }\end{array}$ & No registry & $\begin{array}{l}\text { Mandatory } \\
\text { registration and } \\
\text { filing }\end{array}$ & $\begin{array}{l}\text { Some financing, } \\
\text { especially for } \\
\text { infrastructure } \\
\text { costs }\end{array}$ \\
\hline Alberta & $\begin{array}{l}\text { Reporting for } \\
\text { spills, voluntary } \\
\text { reporting others }\end{array}$ & $\begin{array}{l}\text { Mandatory } \\
\text { registration }\end{array}$ & $\begin{array}{l}\text { Mandatory } \\
\text { registration and } \\
\text { filing }\end{array}$ & - \\
\hline Saskatchewan & $\begin{array}{l}\text { Voluntary } \\
\text { reporting, risk- } \\
\text { based clean up } \\
\text { guidelines }\end{array}$ & $\begin{array}{l}\text { Mandatory } \\
\text { registration and } \\
\text { filing }\end{array}$ & $\begin{array}{l}\text { Mandatory } \\
\text { registration }\end{array}$ & - \\
\hline Manitoba & $\begin{array}{l}\text { Voluntary } \\
\text { reporting, risk } \\
\text { based clean up } \\
\text { guidelines }\end{array}$ & $\begin{array}{l}\text { Mandatory } \\
\text { registration }\end{array}$ & $\begin{array}{l}\text { Mandatory } \\
\text { registration and } \\
\text { filing }\end{array}$ & - \\
\hline Ontario & $\begin{array}{l}\text { Voluntary } \\
\text { reporting, spills } \\
\text { mandatory, risk- } \\
\text { based clean up } \\
\text { guidelines }\end{array}$ & $\begin{array}{l}\text { Mandatory } \\
\text { registration }\end{array}$ & $\begin{array}{l}\text { Mandatory } \\
\text { registration and } \\
\text { filing }\end{array}$ & $\begin{array}{l}\text { Some financing, } \\
\text { especially for } \\
\text { infrastructure } \\
\text { costs }\end{array}$ \\
\hline Quebec & $\begin{array}{l}\text { Mandatory } \\
\text { registration, risk- } \\
\text { based clean up } \\
\text { guidelines }\end{array}$ & $\begin{array}{l}\text { Mandatory } \\
\text { registration for } \\
\text { large tanks, small } \\
\text { tanks exempt }\end{array}$ & $\begin{array}{l}\text { Mandatory } \\
\text { registration and } \\
\text { filing }\end{array}$ & $\begin{array}{l}\text { Quebec-Canada } \\
\text { program for } \\
\text { orphan sites and } \\
\text { Revi-Sols } \\
\text { program }\end{array}$ \\
\hline New Brunswick & $\begin{array}{l}\text { Mandatory } \\
\text { reporting, risk- } \\
\text { based clean up } \\
\text { guidelines }\end{array}$ & $\begin{array}{l}\text { Mandatory } \\
\text { registration of } \\
\text { tanks > } 2000 \mathrm{~L} \\
\text { Mandatory } \\
\text { registration of } \\
\text { waste oil tanks } \\
\end{array}$ & $\begin{array}{l}\text { Mandatory } \\
\text { registration and } \\
\text { filing }\end{array}$ & - \\
\hline $\begin{array}{l}\text { Prince Edward } \\
\text { Is. }\end{array}$ & $\begin{array}{l}\text { Mandatory } \\
\text { reporting, risk- } \\
\text { based clean up } \\
\text { guidelines }\end{array}$ & $\begin{array}{l}\text { Mandatory } \\
\text { reporting for } \\
\text { underground } \\
\text { tanks }\end{array}$ & $\begin{array}{l}\text { Mandatory } \\
\text { registration and } \\
\text { filing }\end{array}$ & - \\
\hline Nova Scotia & $\begin{array}{l}\text { Mandatory } \\
\text { reporting of } \\
\text { pollutant release, } \\
\text { risk-based clean } \\
\text { up guidelines }\end{array}$ & $\begin{array}{l}\text { Mandatory } \\
\text { reporting for } \\
\text { underground } \\
\text { tanks }>2000 \mathrm{~L}, \\
\text { above ground } \\
\text { tanks }>4000 \mathrm{~L}\end{array}$ & $\begin{array}{l}\text { Mandatory } \\
\text { registration and } \\
\text { filing }\end{array}$ & $\begin{array}{l}\text { Provincial } \\
\text { funding for } \\
\text { limited major } \\
\text { sites }\end{array}$ \\
\hline Newfoundland & $\begin{array}{l}\text { Mandatory } \\
\text { registration }\end{array}$ & $\begin{array}{l}\text { Mandatory } \\
\text { registration and } \\
\text { filing } \\
\end{array}$ & $\begin{array}{l}\text { Mandatory } \\
\text { registration }\end{array}$ & - \\
\hline $\begin{array}{l}\text { Government of } \\
\text { Canada }\end{array}$ & $\begin{array}{l}\text { Canadian } \\
\text { Environmental } \\
\text { Protection Act is } \\
\text { primarily a } \\
\text { registration and } \\
\text { information } \\
\text { mechanism }\end{array}$ & - & $\begin{array}{l}\text { Canada Fisheries } \\
\text { Act pertains to } \\
\text { discharges to } \\
\text { water bodies }\end{array}$ & $\begin{array}{l}\text { \$475 M through } \\
\text { March } 2008 \text { for } \\
\text { Federal } \\
\text { Contaminated } \\
\text { Sites, Green } \\
\text { Municipal Funds }\end{array}$ \\
\hline
\end{tabular}

Sources: NRTEE, Provincial Government Websites. 
The Government of Canada has encouraged public consultation at the federal level in the development of legislation and regulation. The Canadian Environmental Protection Act Environmental Registry provides a comprehensive source of information related to activities under the Act. Discharges into water bodies are regulated under the Fisheries Act, while emissions into the air are regulated under the Clean Air Act. Federal funding efforts are substantial, but they are largely limited to the management of federal contaminated sites. In the 2004 Federal Budget, $\$ 3.5$ billion was committed for clean up of federal sites and $\$ 500$ million was committed for shared liability sites. In the 2004 Federal Budget, $\$ 50$ million was committed for the Green Municipal enabling fund (which provides grants for cost-shared feasibility studies, brownfields development plans and environmental site assessments) and \$200 million was committed for the Green Municipal Investment Fund (which established a permanent revolving fund for innovative environmental infrastructure projects), with both funds administered by the Federation of Canadian Municipalities.

The provinces and municipalities have the prime governmental responsibility for the management and development of brownfield sites. These governments generally see their roles as primarily regulatory and advisory, and they usually hold the private sector financially and legally responsible for clean up and development. Private sector responsibilities typically entail: (1) assessment of soil and water quality; (2) undertaking remediation efforts in accordance with provincial criteria for the specific intended use; (3) making provision for future financial liabilities; and (4) financing and implementing the project. In some circumstances, provincial authorities will order private owners to assessment and remediation of a contaminated site. The provinces maintain various disclosure, reporting and filing requirements. Generally, these requirements include mandatory reporting for spills, toxic sites, fuel tanks and generation of wastes and contaminants. As Table 2 indicates, there is a patchwork quilt of regulatory and voluntary requirements across the provinces.

Provincial and municipal financial support for brownfields development is quite limited outside of the Province of Quebec. In 1998, the Government of Quebec established the Revi-Sols (Revitalize Soils) program to promote brownfields development. Phase I (1998-2003) provided \$40 million to help finance study and rehabilitation of contaminated sites at Quebec City and Montreal, while Phase II provides $\$ 50$ million for other municipalities in the province. The other provinces and some municipalities offer tax and financial support on case-by-case basis.

\section{Site rehabilitation cost effectiveness}

In this section, we examine the cost effectiveness of brownfields site rehabilitation using a case study approach. The sites were selected based on three criteria: first, rehabilitation and redevelopment work should be either completely or largely completed; second, there should be detailed information on the site, its pre-habilitation condition, the new uses of the site, rehabilitation costs and construction costs; and, third, the set of cases should cover the range of geographic areas, initial site conditions and final uses in Canada. 
We apply a simplified cost-effectiveness framework in which site rehabilitation activities are undertaken to make it possible to use the site for residential, commercial, industrial or mixed uses. Investors wish to minimize the costs of rehabilitation while maximizing the commercial value of the site. It is natural then to compare the rehabilitation costs with other investment costs as a measure of the cost effectiveness of rehabilitation. We also attempt to estimate the impact of rehabilitation cost of the internal rate on return (IRR) on invested capital. A review of various company reports and the relevant literature suggest that the IRR is typically about $12 \%$ on commercial and industrial investments and about $8 \%$ on residential investments in Canada. Differences in the rates of return reflect the perception that commercial and industrial investments are riskier than residential investments and so require a risk premium in the form of a higher rate of return.

Table 3 summarizes some key dimensions of the ten brownfields rehabilitation cases. These dimensions include site description and new use of the site; former use of the site and its environmental condition before rehabilitation; site cleanup and rehabilitation costs; other investment costs including construction, services and project planning and management; and estimated IRR.

The sites range considerably in size from three acres to 9,000 acres, with an average size of 959 acres. Removing the very large Voisey's Bay site, the average size is just under 100 acres, which appears to be larger than the typical area for the typical case study reported in the literature, which is often in the less than 10 acre range. Average cleanup costs per site are $\$ 26$ million, or about $\$ 20$ million per site without the Voisey's Bay site. Average development costs, exclusive of the cleanup costs, are $\$ 809$ million per site, or $\$ 565$ million without Voisey's Bay. Cleanup costs are thus about $3.1 \%$ of the combined cleanup and development costs, but the range of cleanup costs to total costs varies from $1.2 \%$ for the Cobourg, Ontario site to $55.2 \%$ for the Shawinigan, Quebec site. Estimated rates of return inclusive of cleanup cost are generally fairly reasonable, above $7.5 \%$ for most residential projects and above $11.0 \%$ for most commercial/industrial projects. The two projects where cleanup costs have apparently significantly reduced the rate of return are the Shawinigan project and the first of the two Vancouver projects.

\section{Conclusions}

Years of neglect have left a legacy of contaminated and underutilized brownfield sites in Canada, with attendant environmental, social and economic costs. Rehabilitation of brownfield sites has emerged as a major public issue in Canada over the past twenty years. This paper has explored several dimensions of the brownfields issue in Canada: the size and nature of the brownfields situation by province; the role and extent of federal and provincial government regulatory activities and financing programs; and the cost effectiveness of brownfields site rehabilitation efforts. 
Table 3: $\quad$ Site clean up and development costs, selected sites.

\begin{tabular}{|c|c|c|c|c|c|}
\hline $\begin{array}{l}\text { Site Description and } \\
\text { New Site Use }\end{array}$ & $\begin{array}{l}\text { Former Use and } \\
\text { Initial Site } \\
\text { Condition } \\
\end{array}$ & Site Area & $\begin{array}{l}\text { Cleanup } \\
\text { Costs }\end{array}$ & $\begin{array}{l}\text { Develop } \\
\text { Costs }\end{array}$ & IRR \\
\hline $\begin{array}{l}\text { Moncton, New } \\
\text { Brunswick } \\
\text { Industrial and } \\
\text { commercial park, } \\
\text { some residential } \\
\text { housing, recreational }\end{array}$ & $\begin{array}{l}\text { CN Rail repair } \\
\text { shops; numerous soil } \\
\text { contaminants, } \\
\text { including petroleum } \\
\text { hydro-carbons and } \\
\text { metals }\end{array}$ & 285 acres & $\$ 15 \mathrm{M}$ & $\$ 200 \mathrm{M}$ & $11.2 \%$ \\
\hline $\begin{array}{l}\text { Voisey's Bay, } \\
\text { Newfoundland } \\
\text { Nickel plant, and } \\
\text { other industrial and } \\
\text { commercial }\end{array}$ & $\begin{array}{l}\text { Canadian Forces } \\
\text { military base and } \\
\text { ERCO Phosphorus } \\
\text { Plant; multiple } \\
\text { contaminants }\end{array}$ & $\begin{array}{l}9,000 \\
\text { acres }\end{array}$ & $\$ 81 \mathrm{M}$ & $\$ 3,000 \mathrm{M}$ & $11.7 \%$ \\
\hline $\begin{array}{l}\text { Shawinigan, Quebec } \\
\text { Shopping mall }\end{array}$ & $\begin{array}{l}\text { ICI chlor-alkali, } \\
\text { solvent plants; } \\
\text { mercury, organo- } \\
\text { chloride compounds }\end{array}$ & 3 acres & $\$ 16 \mathrm{M}$ & $\$ 13 \mathrm{M}$ & $5.4 \%$ \\
\hline $\begin{array}{l}\text { Montreal, Quebec } \\
\text { Light industrial and } \\
\text { commercial, } \\
\text { residential dwellings, } \\
\text { recreational }\end{array}$ & $\begin{array}{l}\text { CP Rail shops; heavy } \\
\text { metals, petroleum } \\
\text { hydro-carbons, } \\
\text { polycyclic aromatic } \\
\text { hydrocarbons }\end{array}$ & 309 acres & $\$ 12 \mathrm{M}$ & $\$ 474 \mathrm{M}$ & $11.3 \%$ \\
\hline $\begin{array}{l}\text { Toronto, Ontario } \\
\text { Commercial and } \\
\text { mainly residential } \\
\text { with up to } 20 \text { high } \\
\text { rise buildings }\end{array}$ & $\begin{array}{l}\text { CN Railways site; } \\
\text { metals, heavy metals, } \\
\text { petroleum hydro- } \\
\text { carbons, and other } \\
\text { contaminants }\end{array}$ & 45 acres & $\$ 35 \mathrm{M}$ & $\$ 1,500 \mathrm{M}$ & $7.8 \%$ \\
\hline $\begin{array}{l}\text { Hamilton, Ontario } \\
\text { Commercial and } \\
\text { mainly residential }\end{array}$ & $\begin{array}{l}\text { Bertram Steel } \\
\text { Foundry; creosote, } \\
\text { foundry sand, PCBs, } \\
\text { hydrocarbons }\end{array}$ & 12 acres & $\$ 2 \mathrm{M}$ & $\$ 94 \mathrm{M}$ & $7.8 \%$ \\
\hline $\begin{array}{l}\text { Cobourg, Ontario } \\
\text { Residential and } \\
\text { recreational }\end{array}$ & $\begin{array}{l}\text { Cobourg Ore Port } \\
\text { and petroleum } \\
\text { storage; heavy } \\
\text { metals and petroleum } \\
\text { hydrocarbons }\end{array}$ & 10 acres & $\$ 2 \mathrm{M}$ & $\$ 162 \mathrm{M}$ & $7.9 \%$ \\
\hline $\begin{array}{l}\text { Cornwall, Ontario } \\
\text { Commercial and } \\
\text { mainly residential }\end{array}$ & $\begin{array}{l}\text { Canada Cotton Mills } \\
\text { complex with several } \\
\text { multistory buildings; } \\
\text { contaminated soil, oil } \\
\text { in bunkers }\end{array}$ & 12 acres & $\$ 0.5 \mathrm{M}$ & $\$ 20 \mathrm{M}$ & $7.8 \%$ \\
\hline $\begin{array}{l}\text { Vancouver, British } \\
\text { Columbia } \\
\text { Commercial and } \\
\text { mainly residential } \\
\text { and recreational }\end{array}$ & $\begin{array}{l}\text { Sawmilling, metal } \\
\text { works, foundries, } \\
\text { shipbuilding, salt } \\
\text { distribution; metals, } \\
\text { asbestos, old fuel } \\
\end{array}$ & 50 acres & $\$ 30 \mathrm{M}$ & $\$ 123 \mathrm{M}$ & $6.4 \%$ \\
\hline $\begin{array}{l}\text { Vancouver, British } \\
\text { Columbia } \\
\text { Commercial and } \\
\text { mainly residential }\end{array}$ & $\begin{array}{l}\text { Harbour, railway, } \\
\text { coal gasification; } \\
\text { heavy metals, } \\
\text { creosote, coal tar }\end{array}$ & 163 acres & $\$ 70 \mathrm{M}$ & $\$ 2,500 \mathrm{M}$ & $7.8 \%$ \\
\hline Average & - & 989 acres & $\$ 26 \mathrm{M}$ & $\$ 809 \mathrm{M}$ & $8.5 \%$ \\
\hline
\end{tabular}

Sources: NRTEE, City of Vancouver, Voisey's Bay, Johnson. 
The federal, provincial and municipal governments in Canada have been seeking ways to mitigate the environmental, social and economic impacts of these sites. However, compared to the United States and Western European countries, responsibilities for the regulation and development of brownfield sites in Canada are fragmented and dispersed. In particularly, the federal government has a strong fiscal position but limited responsibilities for brownfields cleanup and rehabilitation, while the provincial and municipal governments, with the exception of oil rich Alberta and British Columbia, have poor fiscal positions but carry the main responsibilities for brownfields rehabilitation and development. This has meant that some cities with strong real estate markets, such as Toronto and Vancouver, have been able to redevelop brownfield sites with relatively little government planning, regulatory or financial support, but this is not a universal situation for all Canadian cities.

Escaping from this dilemma will require phased and integrated action on several fronts. First, there is an urgent need to create a comprehensive and usable database for brownfield sites. Several cities have begun to apply a risk-based land-use approach to database development, and this needs to be implemented by those Canadian cities with major brownfield sites. This is a complicated task, and it might be useful to focus first on larger sites. Second, the main barriers limiting and constraining brownfields development need to be addressed. The most important of these barriers for most cities are financial and liability issues, and while Vancouver and Toronto have made major strides in rehabilitating prestige sites, the comprehensive collaborative management and financing approach pioneered by the Government of Quebec could serve as a useful model for other provinces. Third, the case studies indicate that cooperation between municipalities and private developers, with some support from higher levels of government, can lead to integrated and viable brownfields development. Genuine public consultation, integrated planning which builds on stakeholder needs, and realistic choices on land use which support required rates of return appear to be crucial elements in generating timely brownfields site redevelopment.

\section{References}

[1] De Sousa, C.A., 2006, "Urban brownfields redevelopment in Canada: the role of local government," The Canadian Geographer, 50(3).

[2] Bergman, B. and J. Dumont, 2002, "Fouling our cities," Maclean's Magazine.

[3] Bartsch, C., R. Deane and B. Dorfman, 2001, "Brownfield State of the States: An End-of-session Review of Initiatives and Program Impacts in the 50 States, Washington: Northeast-Midwest Institute.

[4] U. S. Environmental Protection Agency, 2002, Small Business Liability Relief and Brownfields Rehabilitation Act 2002, Public Law 107-118, H. R. 2869.

[5] National Round Table on the Environment and the Economy, 1998, State of the Debate: Greening Canada's Brownfield Sites, Ottawa: National Roundtable on the Environment and the Economy. 
[6] Desousa, C., 2001, "Contaminated sites management: the Canadian situation in international context, Journal of Environmental Management, 62(2).

[7] Benazon, N., 1995, "Soil Remediation: a practical overview of Canadian cleanup strategies and commercially available technologies," Hazardous Materials Management, 7(5).

[8] National Round Table on the Environment and the Economy, 1996a, Contaminated Site Issues in Canada Ottawa: National Roundtable on the Environment and the Economy.

[9] National Round Table on the Environment and the Economy, 1996b, The Financial Services Sector and Brownfield Redevelopment, Ottawa: National Roundtable on the Environment and the Economy.

[10] National Round Table on the Environment and the Economy, 2003, Cleaning Up the Past, Building the Future, Ottawa: National Roundtable on the Environment and the Economy.

[11] Hara, D., 2003, Market Failures and the Optimal Use of Brownfield Redevelopment Policy Instruments, paper presented to the Canadian Economics Association $37^{\text {th }}$ Annual Meeting.

[12] Government of Canada, 2005, Federal, Provincial and Territorial Framework for the Management of Contaminated Sites in Canada, accessed at www.ec.gc.ca/etad/cswg/pub/fed_frame/en/toc_e.htm.

[13] Ford, G., D. Macdonald and M. Winfield, 1994, "Who pays for past sins? Policy issues surrounding contaminated site remediation in Canada," Alternatives 20.

[14] Therrien, R., 1995, "Canadian contaminated land policy," Chemistry and Industry, 13.

[15] Villemaire, R., 2001, "An urban recyclable: brownfield redevelopment as smart growth," Economy \& Technology Journal of Canada.

[16] City of Vancouver, 2006, Southeast False Creek Redevelopment: Property Development Fund Pro Forma Update, Administrative Report, A10.

[17] Voisey's Bay Nickel Company Ltd., 2007, Overview of the Long Harbour Nickel Processing Plant.

[18] Johnson, E., 2001, "Brownfields across Canada," CBC Marketplace, Accessed at www.cbc.ca/consumers/market/files/environ/brownfields. 